\title{
DETERMINING THE EFFECT OF REPLACING COMPOSITE FLOUR MIXTURE WITH CASSAVA STARCH ON NUTRITIONAL AND PHYSICAL PROPERTIES OF CHICKEN SAUSAGES
}

\author{
Rakinahewage Kalpani Lakma Weerasinghe, Indira Wickramasinghe, \\ Madame Arachchige Dulani Somendrika
}

\begin{abstract}
Cassava starch extracted from cassava roots (Manihot esculanta) is a highly used ingredient for most commercial food products and has a high viscosity, water holding capacity, and binding abilities. The objective of this study was to determine the effect of replacing composite flour mixture with cassava starch on the nutritional and physical properties of chicken sausages. A scientific experiment was designed for the sausage formulation to incorporate $50 \%$ to $100 \%$ with cassava modified and native starch compared to the control sample. These samples were evaluated for sensory and textural properties. Nonparametric data obtained through sensory evaluation were analyzed using the Friedman ranking test. According to the test results, the best sample was analyzed for the nutritional toxicological composition and storage stability. According to the statistical analysis, the sample which was 50\% replaced with native cassava starch showed the best sensory profile. The best sample showed average moisture, crude fat, crude protein, total solids, ash, and acid-insoluble ash content of 65.98, 7.19, $8.79,34.02,2.36$, and 0.32 percent respectively. The starch content of the best-ranked sample was 3.12 and the cyanide content of that sample was $1.54 \mathrm{ppm}$ on a dry basis. According to the microbial analysis results, the sausage sample was coliform negative and zero initial plate count was obtained. Besides, the best-ranked fresh chicken sausage was nutritionally acceptable and could keep for 14 days without adding preservatives.
\end{abstract}

Keywords: cassava starch; sausage; nutritional property; toxicological analysis; microbial analysis

\section{INTRODUCTION}

Cassava (Manihot esculanta) is one of the most important food crops in tropical countries. Cassava has higher carbohydrate content and its tapioca starch and modified tapioca starch are highly used as an ingredient of many food products (Zhu et al., 2012). The Sri Lankan annual cassava production in 2015 was 324,097 million Tons and the area of land under the cultivation of cassava is 23,970 Hectares (Statistics, 2016). Over the last decades, cassava production in Sri Lanka grew by $45 \%$ between 2005 and 2015. According to the National Statistics of Household Income and Expenditure Survey, 2012/13 the average monthly consumption of cassava was $171.53 \mathrm{~g}$ per person in Sri Lanka. Sausage is the most popular product among the oldest meat products in history about 1500 B.C. Sausage can be simply defined as a product manufactured from ground meat; mixed with salt, spices, and composite flour mixture; and shaped in some manner, using various sizes and types of casings. Raw sausages are produced without curing and are made from selected cuts of fresh meat. Fresh sausages must always be kept under refrigeration and also must be cooked thoroughly before serving.
The composite flour mixture is included with rice flour, maize powder, milk powder, and bread crumbs. Composite flour mixture has been used as binders in comminuted meat products due to their economic benefits. The amount of composite flour mixture used in processed meat varies depending upon the type of product, manufacturing procedure, and government regulations (Hedrick et al., 1994).

Nowadays, starches are used as binders in processed meat products to absorb moisture, which is released from meat protein during heating. A satisfactory binder should have the ability to hold more moisture throughout the processing, cooking, chilling, and storage of meat products. Today scientific principles are employed to improve production procedures, product quality, and product safety.

To maintain the water-holding ability the binder should also assist in binding the fat and maintaining its dispersion throughout the mix. Starches are commonly added to emulsion-type meat products and are popular not only for their functional properties but also to extend the more expensive lean meat portion of products (Hedrick et al., 1994). The effect is based on the ability of starch to 
Table 1 Ingredients content in sausage formulae.

\begin{tabular}{lccccc}
\hline \multicolumn{1}{c}{ Ingredient } & $\begin{array}{c}\mathbf{a}_{0} \mathbf{b}_{0} \\
\text { CFM 50\% } \\
\text { Starch } \\
\mathbf{5 0 \%}\end{array}$ & $\begin{array}{c}\mathbf{a}_{0} \mathbf{b}_{1} \\
\text { CFM 0\% } \\
\text { Starch 100\% }\end{array}$ & $\begin{array}{c}\text { C } \\
\text { CFM 100\% } \\
\text { Starch 0\% }\end{array}$ & $\begin{array}{c}\text { a1bo } \\
\text { CFM 50\% } \\
\text { Starch 50\% }\end{array}$ & $\begin{array}{c}\text { a.b. } \\
\text { CFM 0\% } \\
\text { Starch 100\% }\end{array}$ \\
\hline Meat \% & 57.6 & 57.6 & 57.6 & 57.6 & 57.6 \\
Emulsion \% & 33.3 & 33.3 & 33.3 & 33.3 & 33.3 \\
Composite Flour Mixture (CFM) \% & 3.05 & 0 & 6.1 & 3.05 & 0 \\
Cassava Native starch \% & 3.05 & 6.1 & 0 & 0 & 0 \\
Cassava Modified starch \% & 0 & 0 & 0 & 3.05 & 3.05 \\
Sugar \& Salts \% & 2 & 2 & 2 & 2 & 2 \\
Spices Mixture \% & 1 & 1 & 1 & 1 & 1 \\
\hline
\end{tabular}

gelatinize when heated in a water-containing medium, thereby binding a relatively large amount of water (Hodge, Osman and Fennema, 1976).

Extracted cassava native starch and modified starch were used for the replacement of composite flour mixture as a source of dietary fiber content (Ruhee et al., 2020) and due to its specific physical properties as high viscosity, water holding capacity, and binding ability. Even though Sri Lanka has higher production of cassava the industrial utilization is limited (Somendrika et al., 2016). Also, cassava has lower postharvest life since it is a perishable food. Increasing the application of cassava starch will directly be beneficial to cassava farmers and for the Sri Lankan economy as it reduces the wastage of cassava. Therefore the objective of the study was to determine the effect of replacing composite flour mixture with cassava starch on the nutritional and physical properties of chicken sausages. Cassava MU51 cultivar was used for the extraction of cassava starch due to the higher availability and higher starch extraction yield $(25 \%-30 \%)$. Textural properties of cassava starch are also important to improve the texture of sausage. Also, the use of cassava starch as a composite flour mixture reduces the cost of sausage raw material.

\section{Scientific hypothesis}

The replacement of composite flour mixture with cassava starch decreases the cost of preparation, improves the organoleptic properties and nutritional composition of fresh chicken sausage.

\section{MATERIAL AND METHODOLOGY}

\section{Samples}

MU51 variety is one of the most cultivated and recommended cassava varieties in Sri Lanka. Thus, the predetermined quantity of cassava MU51 variety was purchased from a cassava cultivator in Bandaragama, Sri Lanka.

\section{Chemicals}

Kjeldahl Tablets (Kjeldahl Tablets, Suphelco, SigmaAldrich Chemie $\mathrm{GmbH}$ ).

Conc. $\mathrm{H}_{2} \mathrm{SO}_{4}$ (Concentrated Sulphuric acid, SigmaAldrich, Sigma-Aldrich Chemie GmbH, 99.999\%).

Conc. NaOH (Sodium Hydroxide, Sigald, Sigma-Aldrich Chemie $\mathrm{GmbH}, \geq 98 \%$ )

95\% Ethyl Alcohol (Etanol, Sigma-Aldrich, SigmaAldrich Chemie $\mathrm{GmbH}, 95 \%$ ).

6N HCl (Hydrochloric Acid, Sigma, Sigma-Aldrich Chemie $\mathrm{GmbH}, 37 \%$ ).
Diethyl Ether (Diethyl Ether, Sigma-Aldrich, SigmaAldrich Chemie GmbH, 99.7\%).

Petroleom Ether ( Petroleom Ether, SIGALD, SigmaAldrich Chemie GmbH, 99\%).

Phenol (Phenol, Sigma-Aldrich, Sigma-Aldrich Chemie $\mathrm{GmbH}, 99 \%$ ).

Potassium cyanide (Potassium cyanide, Sigald, SigmaAldrich Chemie GmbH, 99\%).

Pictric Acid (2,4,6-Trinitrophenol, Sigma-Aldrich, SigmaAldrich Chemie GmbH, 99\%).

Methyl Red (Methyl Red, Sigma-Aldrich, Sigma-Aldrich Chemie GmbH, 99.5\%).

Methyl Blue (Mthyl blue, Sigma-Aldrich, Sigma-Aldrich Chemie GmbH, 70\%).

Peptone (Peptone, Sigma-Aldrich, Sigma-Aldrich Chemie $\mathrm{GmbH})$.

Nutrient agar (Nutrient Agar, Sigma-Aldrich, SigmaAldrich Chemie $\mathrm{GmbH}$ ).

Potato Dextrose Agar (Potato Dextrose Agar, SigmaAldrich, Sigma-Aldrich Chemie $\mathrm{GmbH}$ ).

\section{Instruments}

The Brookfield texture analysis (Model: CT3-4500, Brookfield Engineering, USA).

UV-Vis spectrophotometer (Model: UV mini-1240, SHIMADZU CORPORATION, Japan).

Muffle furnace (Model: SHIMADEN SR1, SHIMADEN CO., LTD, Tokyo).

Polarized Zeeman atomic absorption spectrophotometer (Model ZA3000, HITACHI, Japan).

\section{Laboratory Methods}

Analysis of storage stability - (SLS 516, 2013).

Pre-gelatinized modification (PG) - Rajapaksha et al. (2017).

Nutrition Analysis of sausage - AOAC (2012).

Toxicological Analysis - Spectrophotometric Determination of Cyanide (Picric acid method) by Wood (1965).

Description of the Experiment

Sample preparation:

\section{Extraction of cassava starch}

Cassava starch was extracted according to the method described by Rajapaksha et al. (2017). Roots of the best quality were washed and peeled manually and grated into small pieces. They were ground with normal tap water in a $1: 4$ ratio. The slurry was filtrated through a muslin cloth and the filtrate was allowed to sediment for $4-5$ hours. The sediment starch was separated by decanting and starch was dried by keeping in the mechanical dryer at $60{ }^{\circ} \mathrm{C}$ for 5 hours until the moisture content reduced up to around 
$10 \%$. The dried starch was ground and passed through a 300-micron sieve.

Finally, ground starch was packed in a polyethylene package and was stored $\left(-5^{\circ} \mathrm{C}\right)$ in an airtight container.

Pre-gelatinization modification of cassava starch

Pre-gelatinized modification (PG) was done with slight modifications of the method described by Rajapaksha et al. (2017). As 1:10 starch solution (100 g of starch in $1000 \mathrm{~mL}$ deionized water) was incubated at $65{ }^{\circ} \mathrm{C}$ for 10 minutes. The starch slurry was allowed to sediment for $4-5$ hours. Then starch sediment was dried at $45^{\circ} \mathrm{C}$ till the moisture level dropped to $10 \%-13 \%$.

The pre-gelatinized cassava starch was packed in a polyethylene package and stored under cold room conditions at $-5{ }^{\circ} \mathrm{C}$.

\section{Formulation of sausage}

The basic ingredients used for the chicken sausage were lean meat (minced chicken) fat, ice, isolated soy protein, composite flour mixture, rice flour, maize powder, bread crumbs, milk powder, cassava starch (native and modified), sugar, salt, garlic, black pepper, and chili powder. The amount of ingredients added to sausage preparation is summarized in Table 1.

Number of samples analyzed: Sensory and color analysis - five samples, Nutritional composition, and microbial quality analysis - One sample with three replications for the final sample.

Number of repeated analyses: Three times.

\section{Design of the experiment}

Two cassava starch types (i.e., native cassava starch ( $\mathrm{a}_{0}$ ) and modified cassava starch $\left(a_{1}\right)$ ) were used in the experimental design. In addition, two replacement levels (i.e., $50 \%\left(b_{0}\right)$ and $\left.100 \%\left(b_{1}\right)\right)$ were included.

Four different sausage batters were prepared by replacing composite flour mixture with cassava native starch in 50\% (aobo) and $100 \%\left(a_{0} b_{1}\right)$ levels and with cassava modified starch in $50 \%\left(a_{1} b_{0}\right)$ and $100 \%\left(a_{1} b_{1}\right)$ levels. A sausage was prepared without replacing the composite flour mixture as a control. Other ingredients and additives were incorporated in the formulated batters (Table 1).

The batter was filled into cellulose casings and cooked in steam for 15 minutes until the core temperature becomes $72{ }^{\circ} \mathrm{C}$. Then the prepared sausage was stored at $-5^{\circ} \mathrm{C}$ in a freezer for further analysis.

\section{Analyzing the effect of sensory and physical} properties of replacements (developed formulae) Analysis of sensory attributes of sausages

Six sensory attributes (i.e., Appearance, Colour, Aroma, Flavour, Hardness, Overall acceptability) were analyzed by using the five-point hedonic scale $(5=$ Like extremely, $1=$ Extremely dislike) and 30 untrained panelists.

\section{Texture profile analysis of sausages}

The texture profile (TPA) was analyzed according to the method described by Bourne (2002) with slight modifications by using the Brookfield texture analysis (Model: CT3-4500, Brookfield engineering, USA) at a constant crosshead velocity of $1 \mathrm{~mm} \cdot \mathrm{s}^{-1}$, Trigger point of $10.0 \mathrm{~g}$, and cylindrical sausage samples with a diameter of about $17 \mathrm{~mm}$ and a height of about $10 \mathrm{~mm}$ were used for TPA evaluation. Each test was performed with four replications. Hardness, Springiness, Gumminess, and Chewiness factors were evaluated in the test.
The Color analysis of sausages

Values for the color dimensions $\mathrm{L}^{*}, \mathrm{a}^{*}, \mathrm{~b}^{*}, \mathrm{C}^{*}$, and $\mathrm{h}^{*}$ were measured by using the Colorimeter (Lovibond).

\section{Analyzing the nutritional and toxicological} composition of the developed formulae

\section{Nutritional composition analysis of sausage}

Moisture content, crude protein content, crude fat content ash content, and acid insoluble ash contents were analyzed for the top-ranked sausage samples $\left(\mathrm{a}_{0} \mathrm{~b}_{0}-50 \%\right.$ replacement with Cassava Native starch) following the AOAC (2012) standard methods.

The total solids content was analyzed according to the arithmetic calculation.

The top-ranked sausage sample was subjected to dry ashing (using muffle furnace at $500^{\circ} \mathrm{C}$ ) and analyzed for the presence/quantity of $\mathrm{Na}, \mathrm{K}, \mathrm{Ca}$ and $\mathrm{Mg}$ minerals using Atomic Absorption Spectrophotometric (AAS) method.

Starch content was measured by the method of Dubois (Dubois and Cotter, 1955) with slight modifications.

\section{Toxicological composition analysis (Cyanide content)}

The cyanide content of the top-ranked sausage sample (aobo $-50 \%$ replacement with Cassava Native starch) was analyzed according to Spectrophotometric Determination of Cyanide (Picric acid method) by Wood (1965).

About $10-20 \mathrm{~g}$ of the grounded top-ranked sausage sample was weighed and the weight was recorded. Then the starch sample was introduced into a triple-necked round bottom flask containing $100 \mathrm{~mL}$ of deionized water. About $50 \mathrm{~mL}$ of $2 \mathrm{~N} \mathrm{H}_{2} \mathrm{SO}_{4}$ was added to the round bottom flask. The flask was immediately connected to the steam generator and the distillate was collected in $50 \mathrm{~mL}$ of $\mathrm{Na}_{2} \mathrm{CO}_{3}$ solution till it becomes $200 \mathrm{ml}$. The solution was transferred into a $250 \mathrm{~mL}$ volumetric flask and the volume was made up to $250 \mathrm{~mL}$ using deionized water.

Then $10.00 \mathrm{~mL}$ of the distillate (final solution should be contained $3 \mathrm{~mL}$ of $5 \% \mathrm{Na}_{2} \mathrm{CO}_{3}$ ), and $4 \mathrm{~mL}$ of $1 \%$ Pictric acid were added into a boiling tube and the boiling tube was immersed in a boiling water bath for $12-15$ minutes. Then the solution was left to cool to room temperature and volume was made up to $25 \mathrm{~mL}$.

Finally, the absorbance was measured at $530 \mathrm{~nm}$ in UVVis spectrophotometer (VU mini - 1240) for the developed color of CN- with Picric acid. Reading of absorbance was noted down and $\mathrm{CN}$ - concentration was calculated based on the equation (Cyanide Content = (absorbance +0.03$) / 0.0048$ ) which was been first developed using standard concentration series of KCN solution.

\section{Analysis of storage stability}

The total plate count and coliforms of the prepared sausage samples were determined during the storage using the methods described by SLS 516 (2013).

Total plate count-(SLS 516: part 1 Section 2:2013)

The total plate count of the sausage sample was performed using a Colony count at $30{ }^{\circ} \mathrm{C}$ by the surface plating technique.

Detection and enumeration of Coliform (SLS 516: Part 3 Section 1: 2013)

Coliform detection and enumeration of frozen fries samples were carried by the Most Probable Number (MPN) method. 


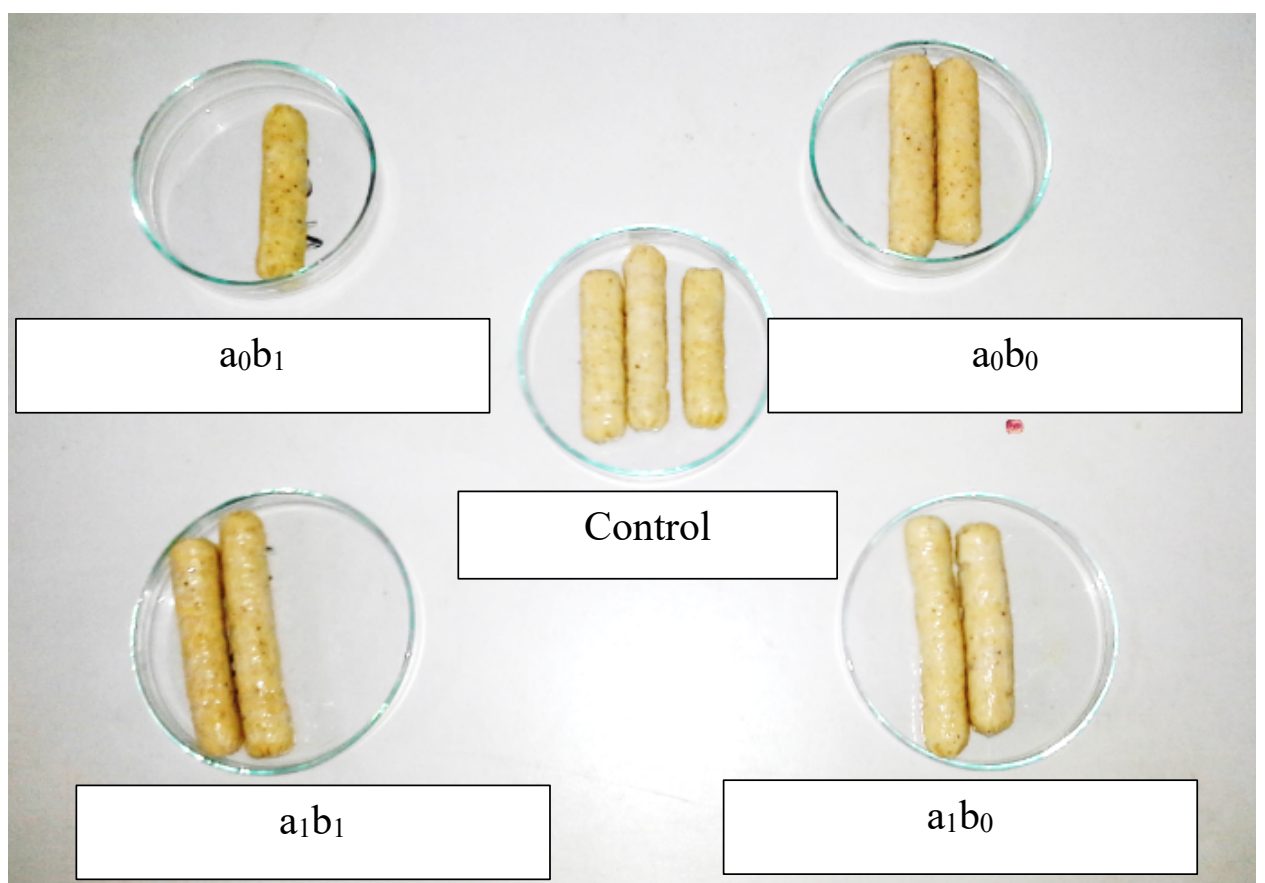

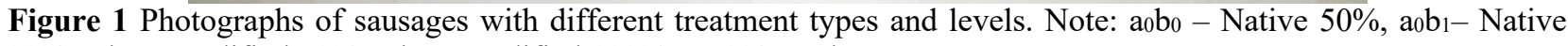
$100 \%, a_{1} b_{0}-$ Modified 50\%, $a_{1} b_{1}-$ Modified 100\%, C- 0\% Replacement.

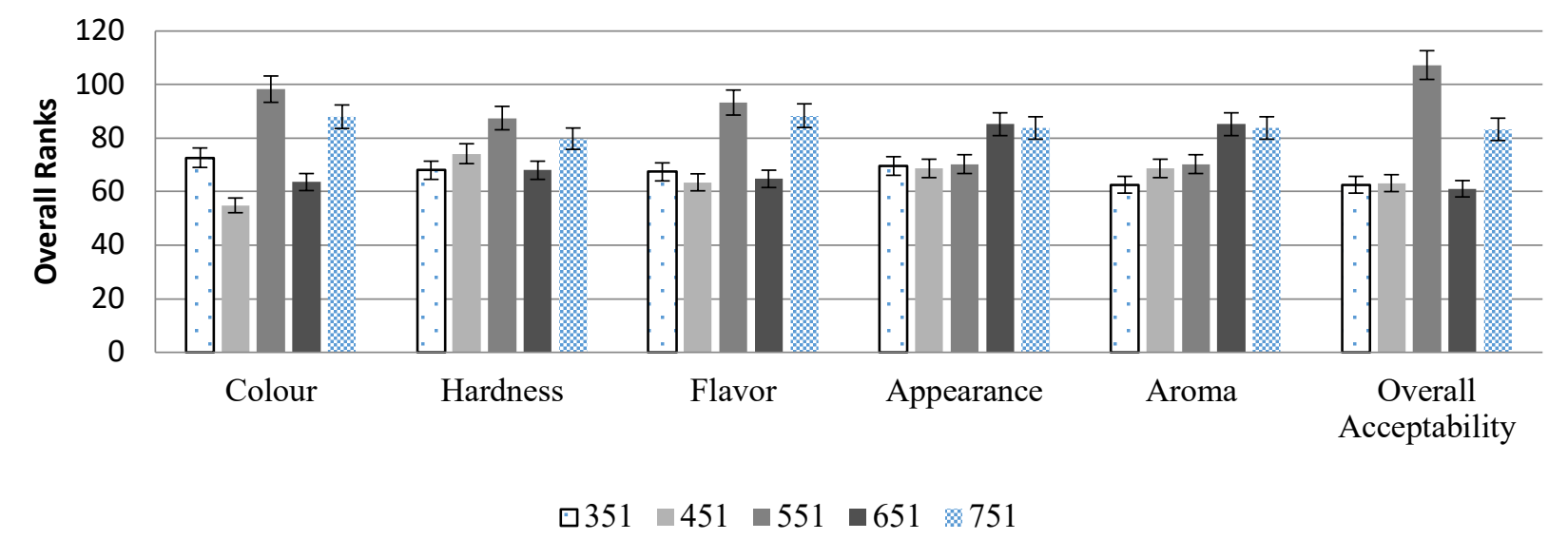

Figure 2 Bar Chart of Friedman overall of Ranks 751 - 50\% replacement with Cassava Native starch, $351-100 \%$ replacement with Cassava Native starch, 451 - 50\% replacement with Cassava Modified starch, 651 - 100\% replacement with Cassava Modified starch, 551 - Control.

\section{Statistical Analysis}

All the parametric and non-parametric data were analyzed by using MINITAB 17 statistical tool. Non-parametric data which are results obtained from the sensory analysis were analyzed using the Friedman ranking test. One-way ANOVA was used to analyze the significant differences of mean values of each sample, followed by Tukey Pairwise comparison test to analyze the samples that had a significant difference in color and texture. Two sample t-test was used to analyze the significant difference in nutritional composition by referring to the reference values obtained from SLS and USDA standards.

\section{RESULTS AND DISCUSSION}

\section{Sensory analysis}

As the sensory profile is the most critical factor results of the sensory analysis were used for the selection of the best sample. The top-ranked sample was 551(Control sausage$0 \%$ replacement) according to the average ranking of Friedman analysis. The second best-ranked sample was 751 $\left(\mathrm{a}_{0} \mathrm{~b}_{0}-50 \%\right.$ replacement with cassava native starch) according to the results of the Friedman ranking analysis.

Results further suggest that the color, appearance, and overall acceptability of all the treatment levels are significantly different from the control sausage sample, $(p<0.05)$ caused by the treatment on that parameters. Since the p-value for hardness, flavor, and aroma of all the 


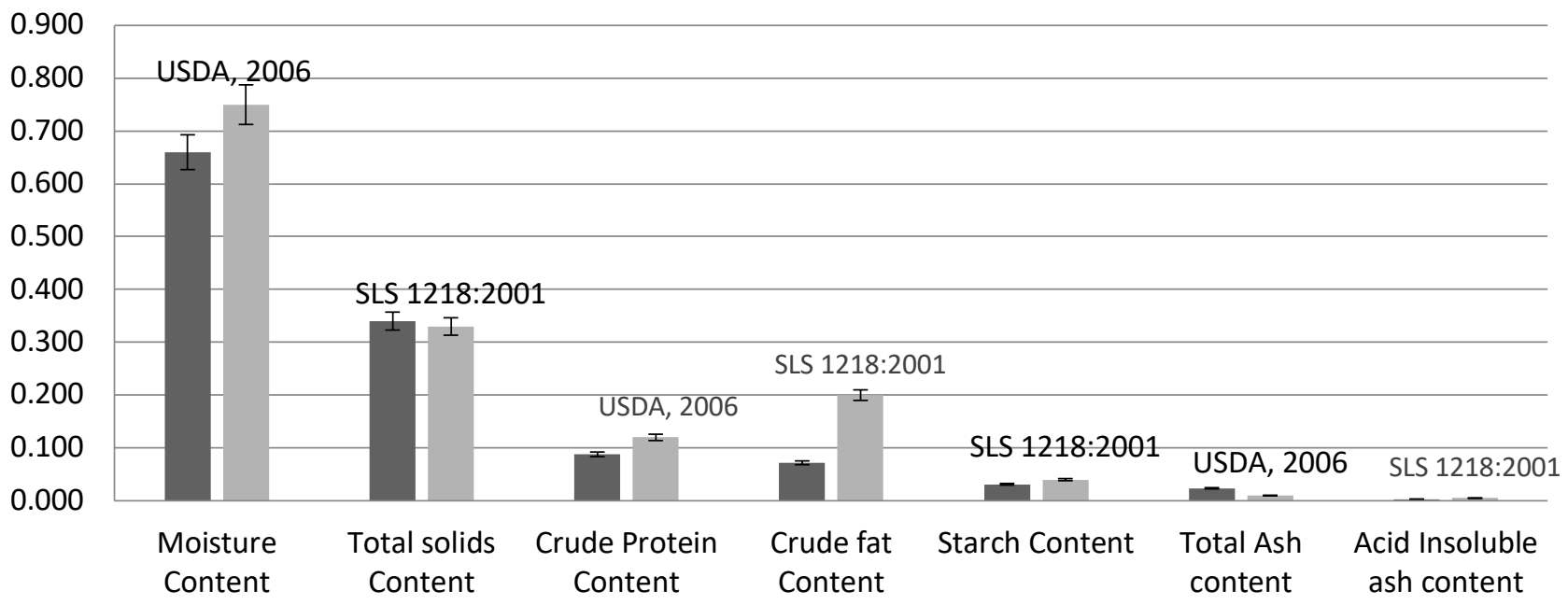

- Composition in 50\% replacement with Cassava Modified starch (T1) sample (per 100g) $\square$ Reference

Figure 3 Bar chart of compares nutritional composition of sausage with referred SLS and USDA standards.

treatment levels was 0.05 , there was no significant effect caused by the treatment on those parameters.

Garcia-Santos et al. (2019) showed that no effect on the sensory parameters including appearance, color, flavor, texture, aroma, and overall acceptance attributes of the Beef and Chicken mix sausages with the treatment of cassava starch. Also, Grizotto et al. (2012) carried out a study with the addition of two types of okara flour in Frankfurter type sausages with partial $(1.5 \%)$ and total $(4.0 \%)$ replacement of texturized soy protein and concluded that the addition of okara flour did not influence sensory acceptance.

\section{Texture profile analysis}

According to the texture profile analysis data $\mathrm{a}_{0} \mathrm{~b}_{0}$ sample has been given $1475 \pm 278(\mathrm{~g})$ for gumminess, $99.5 \pm 19.7$ (mJ) for Chewiness, $0.24 \pm 0.01$ for cohesiveness, and 6.88 \pm 0.06 (mm) for springiness values.

Since the $p$ values were higher than 0.01 (at $1 \%$ significant level) there was no relationship between the treatment level of each treatment type with gumminess, chewiness, cohesiveness, and springiness. However, the addition of wheat fiber had a significant effect on the hardness of sausages (Choe et al., 2013).

According to Chang et al. (2012), the textural characteristic of sausages with modified starch were better than sausage with native starch. But in their research, the starch modifications used were starch acetate, cross-linked esterified starch, and phosphate starch, wherein current research heat moisture treated starch was used for the experiment (Chang et al., 2012).

\section{Colour analysis}

In the colorimetric values analysis $\mathrm{L}^{*}, \mathrm{a}^{*}, \mathrm{~b}^{*}, \mathrm{c}^{*}, \mathrm{~h}_{\mathrm{o}}$ values refer to lightness, redness, yellowness, saturation, and hue, and those dimensions were considered. According to the color values analysis results, there was no significant effect (at 0.05 significant level) by the $50 \%$ replacement by cassava native starch $\left(\mathrm{a}_{0} \mathrm{~b}_{0}\right)$ on lightness and hue. However, that treatment $\left(\mathrm{a}_{0} \mathrm{~b}_{0}\right)$ affected the redness, yellowness, and saturation of sausage.

The $100 \%$ replacement by the cassava native starch $\left(a_{0} b_{1}\right)$ significantly affected (at 0.05 significant level) lightness, redness, and hue. However, it was not significantly affected by yellowness and saturation. A similar result was observed by Hughes, Mullen and Troy (1998). According to Hughes, Mullen and Troy (1998), incorporation of tapioca starch decreased the redness and lightness of the frankfurters, whereas yellowness was not significantly altered.

The 50\% replacement with Cassava Modified starch ( $\left.a_{1} b_{0}\right)$ was significantly influenced (at 0.05 significant level) on the lightness and redness. Also, it was not significantly affected by yellowness and saturation.

But the treatment of $100 \%$ replacement with Cassava Modified starch $\left(a_{1} b_{1}\right)$ was significantly affected (at 0.05 significant level) on the lightness, redness, yellowness, and saturation and significantly not affected on hue according to Tukey's pairwise comparison results.

Since the $\mathrm{p}$ values are less than 0.01 (at $1 \%$ significant level) for the correlation of $\mathrm{a}_{0}$ vs. $\mathrm{L}^{*}, \mathrm{a} 1 \mathrm{vs} . \mathrm{a}^{*}, \mathrm{a}_{1}$ vs. $\mathrm{L}^{*}, \mathrm{a}_{1}$ vs. $\mathrm{a}^{*}, \mathrm{a}_{1}$ vs. $\mathrm{b}^{*}, \mathrm{a}_{1}$ vs. $\mathrm{C}^{*}$ and $\mathrm{a}_{1}$ vs. $\mathrm{h}_{\mathrm{o}}(p<0.01)$ the treatment with cassava starch was significantly affected on color.

According to the Pearson correlation analysis results, there was a strong negative relationship between $\mathrm{a}_{0} \mathrm{vs.} \mathrm{L}^{*}, \mathrm{a}_{1}$ vs. $\mathrm{L}^{*}$, and $\mathrm{a}_{0}$ vs. $\mathrm{h}_{0}$. Also, there was a strong positive relationship between $a_{1}$ vs. $a^{*}, a_{1}$ vs. $b^{*}$, and $a_{1}$ vs. $C^{*}$.

\section{Nutritional Composition analysis}

The top-ranked sample showed average moisture, crude fat, crude protein, total solids, ash, and acid-insoluble ash content of $65.98 \%, 7.19 \%, 8.79 \%, 34.02 \%, 2.36 \%$, and $0.32 \%$ respectively. The starch content of the top-ranked sample was $3.12 \%$. According to Bozhko et al. (2020), the protein content in meat containing semi-smoked sausages 
with different ratios of duck and fish meat varied within $17.90 \%-21.34 \%$.

According to the SLS and USDA standards moisture, crude fat, crude protein, total solids, ash, and acid-insoluble ash contents were $74.6 \%, 33 \%, 12.1 \%, 20 \%, 4 \%, 1 \%$, and $0.5 \%$ respectively (SLS 1218:2001; USDA, 2006). According to the two-sample t-test results, the p-value for total solids content, there was not a significant effect on the total solids content by the $50 \%$ replacement with cassava native starch. Also since the $\mathrm{p}$ values for other nutritional properties are less than 0.05 the replacement was significantly affected on that nutritional property.

Previous research on the effect of substitution of fat with Sorgam and finger-millet showed protein, fat, ash, crude fiber, and carbohydrates contents as $10.4 \%, 3.1 \%, 1.6 \%$, $2.0 \%$, and $70.7 \%$ respectively (Das et al., 2013).

High fat consumption has been associated with cardiovascular diseases, obesity, cancer, and hypertension, among other illnesses (Mapiye et al., 2012; Hygreeva, Pandey and Radhakrishna, 2014).

According to the AAS analysis results, there was a high $\mathrm{Na}$ content in the sausage sample which was $1348.39 \mathrm{mg} .100 \mathrm{~g}^{-1}$. Also, the $\mathrm{K}$ and $\mathrm{Mg}$ contents were $232.15 \mathrm{mg} 100 \mathrm{~g}^{-1}$ and $73.21 \mathrm{mg} .100 \mathrm{~g}^{-1}$ respectively. According to the analysis the absorbance value for the $\mathrm{Fe}$ content was not observed in the standard range. Calculation suggests that the Fe content of the sausage sample should be less than $0.012 \mathrm{mg} .100 \mathrm{~g}^{-1}$.

\section{Toxicological composition}

Cassava starch has a cyanide content of $7.05 \mathrm{mg} \cdot \mathrm{kg}^{-1}$ on a dry basis (Rajapaksha et. al, 2017). The cyanide content in the sausage sample was around $1.54 \pm 0.02 \mathrm{mg} \cdot \mathrm{kg}^{-1}$ on a dry basis. Around $0.0528 \mathrm{mg}$ amount of cyanide contained in added $7.5 \mathrm{~g}$ of starch sample. The cyanide content of the product has been further reduced due to the processing steps in sausage processing such as steaming. (Akingbala, Oguntimein and Abass (1991).

\section{pH analysis}

The detected average $\mathrm{pH}$ value of the sausage was 5.64 \pm 0.11 . The standard level for $\mathrm{pH} 6.6$ has been shown by Venturini et al., (2011). According to Garcia-Santos et al. (2019) addition of resistant starch in sausages increased $\mathrm{pH}$ values where the average varied from 6.10 to 6.21 .

\section{Analysis of storage stability}

Microbial analysis was conducted by TPC and coliform test. Total plate count was analyzed with the purpose of shelf life analysis of the best-ranked sausage and coliform analysis was conducted to determine whether the coliform bacteria are present or absent in the sausage sample.

Sausage is usually exposed to high temperatures by heating till the middle temperature becomes greater than $74{ }^{\circ} \mathrm{C}$ by using the steaming process. But this temperature might not be enough to inactivate all the microorganisms.

Sausages are also re-contaminated with spoilage bacteria during the processing stages followed after cooking. Since that the initial plate count was around 10 C.F.U.g ${ }^{-1}$.

The excessive proliferation of present microflora in the sausage content or on the surface during storage causes economic losses because of spoilage and deterioration.
Especially, lactic acid bacteria are considered to be a major component of the microbial population found on vacuumpackaged sausages (Özdemir, 1997). Lactic acid bacterial growth on the surface of the sausages produces undesirable sensory attributes (Korkeala and Björkroth, 1997).

Findings from research by Onishi. 1957 has shown that the growth of osmophilic yeast in the presence of $18 \% \mathrm{NaCl}$ was limited to the range $\mathrm{pH} 4.0-5.0$ and according to the findings in current research the $\mathrm{pH}$ was higher than this limited range and because of that, the analysis was not done for yeasts and molds.

\section{CONCLUSION}

The best composite flour mixture replacement formula was a $50 \%$ composite flour mixture with cassava native starch. There was no significant effect on the total solids content by the $50 \%$ replacement with cassava native starch and it was significantly affected on moisture content, protein content, fat content, starch content, ash content, acid insoluble ash content, and $\mathrm{pH}$ value of the final product. Shelf life analysis of developed sausage suggests that the product was safer to consume up to 14 days of manufacturing under frozen conditions $\left(-5^{\circ} \mathrm{C}\right)$.

\section{REFERENCES}

Akingbala, J. O., Oguntimein, G. B., Abass, A. B. 1991. Effect of processing methods on quality and acceptability of fufu from low cyanide cassava. Journal of the Science of Food and Agriculture, vol. 57, no. 1, p. 151-154. https://doi.org/10.1002/jsfa. 2740570118

AOAC. 2012. Latimer, G. W. Official methods of analysis of AOAC International. Gaithersburg, Md, AOAC International.

Bourne, M. C. 2002. Food texture and viscosity: Concept and measurement. New York, USA : Elsevier, p. 257-291. https://doi.org/10.1016/B978-012119062-0/50007-3

Bozhko, N. V., Tischenko, V., Pasichnyi, V., Shubina, Y., Kyselov, O., Marynin, A., Strashynskyi, I. 2021. The quality characteristics of sausage prepared from different ratios of fish and duck meat. Potravinarstvo Slovak Journal of Food Sciences volume 15, no. 1, p. 26-32. https://doi.org/10.5219/1482

Chang, Y., Wang, P., Xu, X. L., Jiang, S. S. 2012. Effect of different kinds of modified tapioca starch on the qualities of chicken sausage. Science and Technology of Food Industry, vol. 7.

Choe, J. H., Kim, H. Y., Lee, J. M., Kim, Y. J., Kim, C. J. 2013. Quality of frankfurter-type sausages with added pig skin and wheat fiber mixture as fat replacers. Meat Science, vol. 93, no. 4,4 p. 849-854. https://doi.org/10.1016/j.meatsci.2012.11.054

Das, S. K., Prabhakaran, P., Tanwar, V. K., Biswas, S. 2015. Effect of some plant starches and carrageenan as fat substitutes in chicken patties. Journal of animal science, vol. 93, no. 7, p. 3704-3712. https://doi.org/10.2527/jas.2013-6667

Dubois, K. P., Cotter, G. J. 1955. Studies on the toxicity and mechanism of action of dipterex. AMA Arch. industr. Hlth., 11.

Garcia-Santos, M. D. S. L., Conceicao, F. S., Villas Boas, F., Salotti De Souza, B. M., Barretto, A. C. D. S. 2019. Effect of the addition of resistant starch in sausage with fat reduction on the physicochemical and sensory properties. Food Science and Technology, vol. 39, p. 491-497. https://doi.org/10.1590/fst.18918

Grizotto, R. K., Andrade, J. C., Miyagusku, L., Yamada, E. A. 2012. Physical, chemical, technological and sensory characteristics of Frankfurter type sausage containing okara 
flour. Food Science and Technology, vol. 32, no. 3, p. 538-546. https://doi.org/10.1590/S0101-20612012005000076

Hedrick, H. B., Aberle, E. D., Forrest, J. C., Judge, M. D., Merkel, R. A. 1994. Principles of meat science. Iowa: Kendall, p. 351.

Hodge, S., Osman, M., Fennema, O. R. 1976. Food Chemistry. Principles of Food Science Part 1. p. 102.

Hughes, E., Mullen, A. M., Troy, D. J. 1998. Effects of fat level, tapioca starch and whey protein on frankfurters formulated with 5\% and 12\% fat. Meat Science, vol. 48, no. 12, p.169-180. https://doi.org/10.1016/S0309-1740(97)00087-9 Hygreeva, D., Pandey, M. C., Radhakrishna, K. 2014. Potential applications of plantbased derivatives as fat replacers, antioxidants and antimicrobials in fresh and processed meat products. Meat Science, vol. 98, no. 1, p. 47-57. https://doi.org/10.1016/j.meatsci.2014.04.006

Korkeala, H. J., Björkroth, K. J. 1997. Microbiological spoilage and contamination of vacuum-packaged cooked sausages. Journal of Food Protection, vol. 60, no. 6, p.724731. https://doi.org/10.4315/0362-028X-60.6.724

Mapiye, C., Aldai, N., Turner, T. D., Aalhus, J. L., Rolland, D. C., Kramer, J. K. G., Dugan, M. E. R. 2012. The labile lipid fraction of meat: From perceived disease and waste to health and opportunity. Meat Science, vol. 92, no. 3, p. 210-220. https://doi.org/10.1016/j.meatsci.2012.03.016

Onishi, H. 1957. Studies on osmophilic yeasts: Part I. Salttolerance and sugar-tolerance of osmophilic soy-yeasts. Bulletin of the Agricultural Chemical Society of Japan, vol. 21, no. 3, p.137-142. https://doi.org/10.1271/bbb1924.21.137

Özdemir, H. 1997. Distribution of lactobacilli isolated from vacuum-packaged spoiled and unspoiled sausages. Ankara Üniversitesi Veteriner Fakültesi Dergisi, vol. 44, p. 163-168.

Rajapaksha, K. D. S. C. N., Somendrika, M. A. D., Wickramasinghe, I. 2017. Nutritional and toxicological composition analysis of selected cassava processed products. Potravinarstvo Slovak Journal of Food Sciences, vol. 11, no. 1, p. 35-42. https://doi.org/10.5219/689

Ruhee, R. T., Sams, S., Begum, A., Alam, M. K., Begum, P., Khatun, M., Kawser, M., Saberin, S., Ahsan, M., Islam, S. N., 2020. Dietary fibre content in ethnic and unconventional vegetables and fruits growing in Bangladesh. Potravinarstvo Slovak Journal of Food Sciences, vol. 14, no. 1, p. 1-9. https://doi.org/10.5219/1202

SLS 1218. 2001. Sri Lanka Standard Institute, 2001. Sri lanka standard specification for comminuted meat products, SLS 1218, Sri Lanka.

SLS 516. 2013. Sri Lanka Standard Institute, 2013. Sri Lankan Standard for microbiological analysis, SLS 516, Sri Lanka.

Somendrika, M. A. D., Wickramasinghe, I., Wansapala, M. A. J., Peiris, S. 2016. Material flow analysis of Cassava crocket manufacturing process from raw cassava (Manihot esculenta) roots. International Journal of Innovative Research in Technology, vol. 2, no. 9, p. 32-35.

Statistics. 2016. Central Bank of Sri Lanka. Economic and Social Statistics of Sri Lanka. XXXVIII IS, p.183. Bourne, M. C., 2002. Food texture and viscosity: Concept and measurement. New York, USA : Elsevier, Inc.

USDA. 2006. Composition of Foods Raw, Processed. Prepared USDA National Nutrient Database for Standard Reference, Release 19, 2006.

Venturini, A. C., Cavenaghi, Â. D., Castillo, C. J. C., Quiñones, E. M. 2011. Sensory and microbiological evaluation of uncured fresh chicken sausage with reduced fat content. Food Science and Technology, vol. 31, no. 3, p. 629-634. https://doi.org/10.1590/S0101-20612011000300012
Wood, B. T. 1965. The Cyanogenic Glucoside content of cassava and cassava products. Journal of the Science of Food and Agriculture, vol. 16, p. 300-305. https://doi.org/10.1002/jsfa.2740160603

Zhu, X. S., Xu, X. L., Min, H. H., Zhou, G. H. 2012. Occurrence and characterization of pale, soft, exudative-like broiler muscle commercially produced in China. Journal of Integrative Agriculture, vol. 11, no. 8, p. 1384-1390. https://doi.org/10.1016/S2095-3119(12)60137-3

\section{Funds:}

This research received no external funding.

\section{Acknowledgment:}

The authors express their gratitude to the University of Sri Jayewardenepura, Sri Lanka for the provided facilities to complete the research study successfully and to Ms. Sashie Abeywickrema, Research Candidate (Sensory Neuroscience), Department of Food Science University of Otago, Dunedin, New Zealand, for her generous assistance in language correction.

\section{Conflict of Interest:}

No conflicts of interest to declare regarding the present study.

\section{Ethical Statement:}

Not applicable.

\section{Contact address:}

*Rakinahewage Kalpani Lakma Weerasinghe, Department of Food Science and Technology, Faculty of Applied Sciences University of Sri Jayewardenepura, Nugegoda, Sri Lanka, Tel.: +94 702537418,

E-mail: klakma707@gmail.com

ORCID: https://orcid.org/0000-0001-7455-1276

Indira Wickramasinghe, Department of Food Science and Technology, Faculty of Applied Sciences University of Sri Jayewardenepura, Nugegoda, Sri Lanka, Tel.: +94 716861908 ,

E-mail: indiraw@sjp.ac.lk

ORCID: https://orcid.org/0000-0003-1805-4923

Madame Arachchige Dulani Somendrika, Department of Food Science and Technology, Faculty of Applied Sciences University of Sri Jayewardenepura, Nugegoda, Sri Lanka, Tel.: +94 702758312,

E mail: dsomendrika@sjp.ac.lk

ORCID: https://orcid.org/0000-0003-1958-9137

Corresponding Author: * 